TARBIYA: Journal of Education in Muslim Society, 5(1), 2018, 78-85

in Muslim Societ'

\title{
DEVELOPMENT OF LEARNING VIDEO USING GUIDED INQUIRY METHOD ON CIRCULAR MOTION SUBJECT TO IMPROVE STUDENT LEARNING OUTCOMES
}

\author{
I Made Astra, Raihanati Raihanati, Syarifah Hafizah \\ Physics Department, State University of Jakarta, Indonesia \\ E-mail: imadeastra@gmail.com
}

\author{
Received: $12^{\text {th }}$ April 2018; Revised: $23^{\text {th }}$ Mei 2018; Accepted: $28^{\text {th }}$ June 2018
}

\begin{abstract}
This study aims to develop a learning video on circular motion subject as a physics learning media for high school students. The developed video is prepared based on the guided inquiry learning stage and completed with the Student Worksheet. This research used the Research and Development (R\&D) method, with the ADDIE model. The developed video has been through feasibility test with the achievement percentage of $91.8 \%$ from a material expert, $96.8 \%$ from media expert, and $85.9 \%$ from learning expert with excellent interpretation. The product trial results show the percentage of achievement of $81.7 \%$ from educator and $89.4 \%$ from the learner. There is an increase in result was 54.4 to 79.8 with a normalized gain test of 0.56 Based on the result of the feasibility test and experiment, it can be concluded that instructional video using guided inquiry method in circular motion subject is worth to be used as physics learning media in senior high school and improved students' learning outcomes in the medium category.
\end{abstract}

Keywords: video; guided inquiry; learning outcomes

\section{Abstrak}

Penelitian ini bertujuan untuk mengembangkan video pembelajaran pada materi gerak melingkar sebagai media pembelajaran fisika untuk siswa SMA. Video yang dikembangkan disusun berdasarkan tahapan pembelajaran inkuiri terbimbing dan dilengkapi dengan Lembar Kerja Siswa (LKS). Penelitian ini menggunakan metode Research and Development $(R \& D)$, model ADDIE. Video yang dikembangkan telah melalui tahap uji kelayakan dengan persentase pencapaian $91.8 \%$ menurut ahli materi, 96.8\% menurut ahli media, dan $85.9 \%$ menurut ahli pembelajaran dengan interpretasi sangat baik. Hasil uji coba produk menunjukkan persentase pencapaian $81.7 \%$ menurut pendidik dan $89.4 \%$ menurut peserta didik. Melalui uji coba kepada peserta didik, didapatkan kenaikan dari hasil pretest sebesar 54.4 menjadi 79.8 saat postest. Berdasarkan hasil uji kelayakan dan uji coba dapat disimpulkan bahwa video pembelajaran menggunakan metode inkuiri terbimbing pada materi gerak melingkar hasil pengembangan telah layak digunakan sebagai media pembelajaran fisika SMA.

Kata kunci: video; inkuiri terbimbing; hasil belajar

How to Cite: Astra, I M., Raihanati, Hafizah, S. (2018). Development of Learning Video Using Guided Inquiry Method on Circular Motion Subject to Improve Student Learning Outcomes. TARBIYA: Journal of Education in Muslim Society, 5(1), 78-85. doi:10.15408/tjems.v5i1.7688.

Permalink/DOI: http://dx.doi.org/10.15408/tjems.v5i1.7688 


\section{Introduction}

Physics is the study of natural phenomena regarding matter and energy. As a basic of science, physics has characteristics that include the building of the science process which includes facts, concepts, principles, laws, postulates, and scientific theories and methodologies (Mundilarto, 2002). Physics in learning has concrete and abstract images. The concrete application of physics can be easily observed in daily life, but the abstract concept of physics is difficult to observe directly. One of the abstract concepts in physics is circular motion which primarily describes vectors in quantities such as angular velocity, linear velocity, and centripetal acceleration. Therefore, it takes a media that can help the learner to visualize the abstract concept. The video is a set of components or media that can display both images and sound at the same time. Videos can present information, present processes, explain complex concepts, teach skills, abbreviate or prolong the time, and influence attitudes. A video can help visualize the abstract concept in circular motion.

Learning physics Circular Motion in senior high school are easily understood by learners when using a video independently. This was based on a questionnaire of 80 senior high school students in Jakarta which stated that $92.5 \%$ like learning activities when there is video in it. Ida Ayu Gede (2014) states that there is a correlation between taking notes on attitudes and memory abilities in the learning process (Dewi, Ida A.G.B.P., 2014). By writing information in notes, students can process information and improve memory. A video provides 50\% information (based on Edgar Dale's conical experience). However, if it is modified into a video with material content, real-life examples, discussion of problems and worksheets to record the information that has been received through videos, it will increase the learner's self-absorption.

Based on the questionnaire of the needs assessment of 8 physics teachers in Jakarta and its surrounding areas, $75 \%$ of teachers have implemented scientific learning and assessing scientific learning with guided inquiry method effectively through learning in the classroom. Inquiry learning method is a series of learning activities that emphasize the critical and analytical thinking process to find answers to a questionable problem. There is a total percentage of $100 \%$ teachers stated that the development of learning videos using guided inquiry method for circular motion material equipped with Student Worksheet is needed. They claimed that the current learning videos on the internet are just a video that is done in a classroom with someone explained in a blackboard or a group of learners who are doing a simple experiment. This available video lesson generally shows only a small part of the material contained in the basic competencies. Hence, a video with complete content which can visualize learning materials appropriately to guide students in finding the concept and learning materials is needed.

The video is a set of components or media that can display both images and sound at the same time (Sukiman, 2012). The nature of a video is turning an idea into images and sound impression through a recording process, and its broadcast involves in a particular technology (Prastowo, 2014). A video is also a non-print material that is rich in information and complete because the students can control the video directly. Also, a video adds a new dimension to learning because of the characteristics of the video that can present moving images accompanied by sounds to students (Daryanto, 2013). Thus, students feel like they are in the same place as the video program. From those expert opinions above, it can be synthesized that a learning video is an audio-visual media 
(moving image impressions accompanied by sound) which contained ideas or learning messages to improve the quality of the learning process and to make it more effective.

Guided inquiry method is a learning method which attempts to build knowledge and meaning by involving students to formulate questions and to investigate the answers (Hamruni, 2009). Inquiry method emphasizes the process of inquiry and answering questions. Inquiry method is an investigation of ideas, questions, or problems. The process involves gathering information, building knowledge, and developing a deep understanding of what is being investigated (Sani, 2014). Inquiry learning method is a series of learning activities that emphasize the critical and analytical thinking process and find the answer to a question. The thought process itself is usually done through question and answer between teachers and students (Sudjana, 2004). In inquiry learning, the learning process should be viewed as a stimulus that can challenge students to do learning activities. Thus, students would do more activities alone or in the group to solve problems with teacher guidance.

In guided inquiry learning, teachers have a more active role in determining problems and finding solutions. From the variation of inquiry learning perspectives', guided inquiry method has a characteristic in which the learning topic, the question, and the learning material is determined by the teacher, while the design and the learning procedure are formulated together by the teacher and the student, and the result or analysis and conclusion is determined by the student. According to Sanjaya, the steps of the learning process using inquiry methods are as follows (Sanjaya, 2013):

Orientation: The orientation step is a step to foster a responsive atmosphere or learning climate. In this step, the teacher stimulates and invites students to think how to solve the problems.

Formulating problems: Formulating problems is a step in bringing students to a puzzle-filled problem. The problem presented is a matter that challenges students to think about how to solve the puzzle. Students will gain invaluable experience in an effort to develop mentally through the process of thinking.

Formulating hypotheses: A hypothesis is a temporary answer to a problem under study. As a temporary answer, the hypothesis needs to be verified. Hypothesis estimates must have a solid ground of thought so that it is rational and logical.

Collecting data: Collecting data is the activity of capturing the information needed to test the proposed hypothesis. The role of teachers in this stage is to ask questions that can encourage students to think about finding the information they need.

Testing the hypothesis: Testing the hypothesis is to determine the answer it deems acceptable by the data or information obtained based on the data collection. The truth of the answer given is not only based on argumentation but must be supported by the data found and accountable.

Formulating conclusions: Formulating conclusions is the process of describing findings obtained based on the results of testing the hypothesis. To reach an accurate conclusion the teacher should be able to show students what data is relevant.

Physics learning on circular motion subject is studied by high school students of class $\mathrm{X}$ concerning the revised 2013 curriculum. In the circular motion subject, there are abstract concepts that need to be visualized through the video to make learners easier to understand the whole circular motion topic. The circular motion topic that will be featured in the video 
includes the main topics which are uniform circular motion and circular motion uniformly accelerated. The range of uniform circular motion subject is: 1) Understanding uniform circular motion; 2) Magnitude in circular motion: period, frequency, angular velocity, linear velocity, centripetal acceleration; 3) The analogy of uniform circular motion with uniform rectilinear motion; 4)Wheel relations: centered wheels connection, tangential wheels connection, wheels connected with belts/chains.

While the scope of circular motion uniformly accelerated, namely: 1) Understanding circular motion uniformly accelerated; 2) Acceleration prevailing in circular motion uniformly accelerated; 3) The analogy of circular motion changes irregularly with uniform rectilinear accelerated motion.

\section{Method}

This study used the Research and Development (R\&D) method, with the ADDIE model. Research and development method is a kind of methods that are applied to develop and validate product implemented in the learning process (Putra, 2011; Sugiyono.2011). The video development steps were undertaken to produce the learning video summarized in table 1.

Table 1. Video development steps

\begin{tabular}{ll}
\hline Steps & \multicolumn{1}{c}{ Activity } \\
\hline Analyze & $\begin{array}{l}\text { Preliminary study: review existing learning } \\
\text { videos and things that need to be } \\
\text { developed } \\
\text { - }\end{array}$ \\
& $\begin{array}{l}\text { Analyze curriculum and learning methods } \\
\text { refers to learning by guided inquiry } \\
\text { method } \\
\text { - }\end{array}$ \\
& Analyze the needs of teachers and learners. \\
& Analyze the devices needed which include \\
& hardware and software to support video \\
& designs. \\
\hline Design & $\begin{array}{l}\text { Design the design of learning products in } \\
\text { the form of a storyboard that includes } \\
\text { planning the story ideas, visualization, } \\
\text { narration, and the duration of the video }\end{array}$
\end{tabular}

will be developed.

- Design the form and arrangement of student worksheets that will be integrated with the developed learning videos.

\begin{tabular}{|c|c|}
\hline De & $\begin{array}{l}\text { - Product development: record } \\
\text { predetermined events in the storyboard, } \\
\text { video compiled and edited using Adobe } \\
\text { Premiere Pro CS6 software according to } \\
\text { the storyboard. } \\
\text { - Feasibility tests by material experts, media } \\
\text { experts, and learning experts. } \\
\text { - Revisions: improved products based on } \\
\text { comments, suggestions, and feedback } \\
\text { from experts. }\end{array}$ \\
\hline & $\begin{array}{l}\text { - Product tested to } 34 \text { students and one } \\
\text { educator (senior high school physics } \\
\text { teacher). } \\
\text { - Distribute questionnaires to measure and } \\
\text { know the response of learners and } \\
\text { educators about products that have been } \\
\text { developed. }\end{array}$ \\
\hline
\end{tabular}

Evaluate - Fixed final-stage video products based on evaluation results in previous stages.

\section{Result and Discussion}

The media produced through this development research is a circular motion learning video. The subject presented in the video involves uniform circular motion (meaning, the magnitude of uniform circular motion, the analogy of uniform circular motion with uniform rectilinear motion, wheel ties) and circular motion uniformly accelerated (meaning, acceleration in circular motion uniformly accelerated, and analogy circular motion uniformly accelerated with uniform rectilinear accelerated motion). This learning video contains the elaboration of subject matter and mathematical formulation for the formation of learners' concepts, application of concepts in daily life and technology, as well as examples of discussion of the matter on each sub-subject matter.

The learning video has been developed with a total duration of 34 minutes (4 minutes of circular motion orientation, 20 minutes of uniform circular motion, and 10 minutes of and 
circular motion uniformly accelerated). The images and videos shown in this learning video are from the documentation of the researcher and the YouTube site by listing the source at the bottom right of the video. The entire narrative (dubbing) in the video is done by the researcher to make the learning video easier for learners to understand the visual.

There is the addition of background music in the form of instrumental music and sound effects which is adjusted to the researcher's voice to make the video lessons interesting and not boring. The main characteristics of the instructional videos that have been developed are arranged based on guided inquiry stages with the following stages: (1) orientation, (2) formulating problems, (3) formulating hypotheses, (4) collecting data, (5) testing hypotheses, (6) formulate conclusions, and completed with student worksheets to facilitate learners in every learning stage using video with guided inquiry method.

Student worksheet as a complement to the video is prepared as a media that supports learners to be active in learning activities. The resulting videos and student worksheets are available online and offline. Online video can be viewed through the youtube site on the link https://www.youtube.com/watch?v=PFyeXEjv1lc

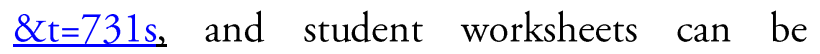
download on the links provided below the video while offline can be through hardware such as compact disk and flash which is given directly to teachers in school.

Furthermore, the feasibility of the use of learning developed video can be seen through the feasibility test of the subject matter experts, media experts, and learning experts. The result of the feasibility test obtained is used as a reference to improve the developed product. Product trials were conducted for students and high school physics teachers. Implementation of product trial conducted to high school students who have studied the circular motion subject to find out whether the developed product can increase students' knowledge on circular motion topic. The product developed is tested to high school physics teacher as a manager of learning resources (facilitator) in the classroom to get a feasibility assessment of the video product that has been developed.

\section{Feasibility Test}

The feasibility test phase involves one subject expert, one media expert; and one learning expert and the product testing stage involved one high school physics teacher and 34 students

\section{Feasibility Test Result by Subject Expert}

The feasibility of the product regarding the subject matter is tested using a test sheet which contained 26 items of statement which cover several aspects. Table 2 is the data obtained from material experts:

Based on the result of the feasibility test by the subject expert, it can be seen from the table above that the average achievement is $91.8 \%$. According to the Likert-scale interpretation, this score indicates that the integrated video product and student worksheet developed regarding subject matter are considered feasible to be used as physics learning media with a very good predicate.

\section{Feasibility Test Results by Media Experts}

The feasibility of the product regarding media is tested using a test sheet which contained 32 statement items which cover several aspects. Table 3 is the data obtained from media experts:

Based on the feasibility test result by media expert, it can be seen from the table above that the average achievement of the overall aspect is 96.8\%. According to Likert-scale interpretation, 
this score indicates that the integrated video product and student worksheet developed regarding media aspects are considered feasible to be used as a physics learning media with the very good predicate.

\section{Feasibility Test Results by Learning Expert}

The feasibility of the product regarding learning is tested using a test sheet which contained 27 statement items which cover several aspects. Table 4 is the data obtained from learning experts:

Based on the feasibility test result by learning expert, it can be seen from the table above that the average achievement of the overall aspect is $85.9 \%$. According to Likert-scale interpretation, this score indicates that the integrated video product and student worksheet developed regarding suitability of approach/method, effectiveness, and efficiency of competency achievement, presentation sequence, and conformity with target characteristics are considered to be excellent. While the appropriateness of evaluation with indicator and competence and evaluation support the mastery of the material are considered to be good. Hence, from the data above it can be concluded that the media developed are considered feasible to be used as a medium of learning physics.

Table 2 . Feasibility test results by subject matter experts

\begin{tabular}{lll}
\hline Aspects tested & $\begin{array}{l}\text { Percentage } \\
\text { Achievements }\end{array}$ & of \\
Subject matter accuracy & $95 \%$ & Very good \\
Depth and breadth of matter & $80 \%$ & Good \\
The suitability of the subject matter with the curriculum & $100 \%$ & Very good \\
Audiovisual compliance with subject matter & $92.5 \%$ & Very good \\
Subject matter adequacy & $80 \%$ & Good \\
Clarity of subject matter description and sampling & $95 \%$ & Very good \\
Proficiency & $100 \%$ & Very good \\
Average & $\mathbf{9 1 . 8 \%}$ & Very good
\end{tabular}

Table 3. Feasibility test results by media experts

\begin{tabular}{|c|c|c|}
\hline Aspects tested & $\begin{array}{l}\text { Percentage } \\
\text { Achievements }\end{array}$ & Interpretation \\
\hline Content quality & $96 \%$ & Very good \\
\hline Language & $100 \%$ & Very good \\
\hline Visual appearance & $91.4 \%$ & Very good \\
\hline Sound & $100 \%$ & Very good \\
\hline Ease of use & $100 \%$ & Very good \\
\hline Implementation & $100 \%$ & Very good \\
\hline Average & $96.8 \%$ & Very good \\
\hline
\end{tabular}

Table 4. Feasibility test results by learning experts

\begin{tabular}{|c|c|c|}
\hline Aspects tested & $\begin{array}{l}\text { Percentage of } \\
\text { Achievements }\end{array}$ & Interpretation \\
\hline Suitability of approach/method & $86.7 \%$ & Very good \\
\hline $\begin{array}{l}\text { Effectiveness and efficiency of competency } \\
\text { achievement }\end{array}$ & $84.4 \%$ & Very good \\
\hline Presentation sequence & $93.3 \%$ & Very good \\
\hline Conformity with target characteristics & $90 \%$ & Very good \\
\hline $\begin{array}{l}\text { The evaluation, indicators, and competencies are } \\
\text { appropriate. }\end{array}$ & $80 \%$ & Good \\
\hline Evaluation supports the mastery of the material & $80 \%$ & Good \\
\hline Average & $85.9 \%$ & Very good \\
\hline
\end{tabular}




\section{Product Trial on High School Students}

Learning video products and integrated student worksheets that have been through feasibility test by subject experts, media experts, and learning experts are then tested to 34 high school students of year XI who has studied circular motion material in year $\mathrm{X}$.

The trial begins with a pre-test of 15 questions about physics problems in a circular motion to measure the learner's initial ability. After given pre-test questions, the developed video learning product is displayed in front of the classroom and students are given an integrated student workbook to record important information present in the video. While the learner watches the video, the researcher pauses some parts of the video and assign the learner to record initial knowledge, hypotheses, or solve examples of circular motion problems on the student worksheets that are available. When finished, learners are asked to do post-test questions. The post-tests questions are made similar to the pre-test's questions to test if there is any difference from using the media developed.

Based on tests that have been done, the average value of the pre-test is 54.4 , and the average value of the post-test is 79.8. Based on those values, it can be seen that there is an increase in post-test results. The normalized ngain test shows that after watching the video and rewriting information on the worksheet, student's learning outcomes improve by 0.56 points and it is in the medium category.

Beside doing post-test questions, learners also respond to a product that has been developed through questionnaires. This questionnaire contains 20 items of statement which covered several aspects. Below is the data obtained from test results to learners, see figure 3.

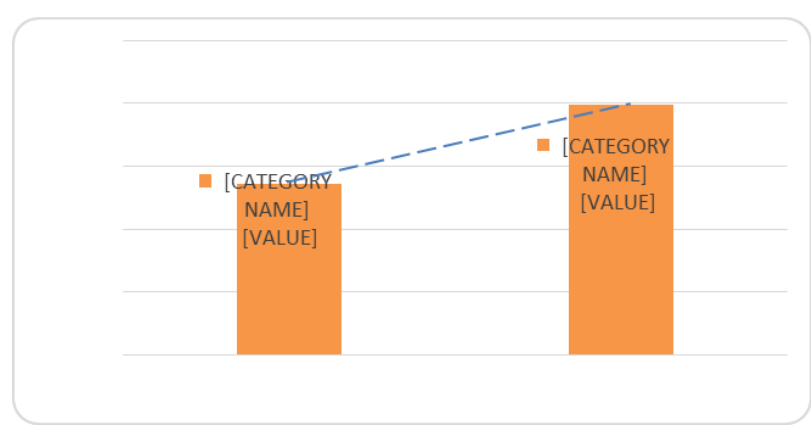

Whereas the normalized gain test can be calculated as follows: $\mathrm{N}-$ gain normalized $=\frac{\text { post test score }- \text { pre }- \text { test score }}{\text { maximum score }- \text { pre }- \text { test score }}$

$$
=\frac{79.8-54.5}{100-54.5}=\mathbf{0 . 5 6}
$$

Figure 3. Pre-test and Post-test Result Charts

Based on table 5, the obtained average achievement of the overall aspect is $89.4 \%$. According to Likert-scale interpretation, this score indicates that the integrated video product and student worksheet developed have an excellent response by learners as a physics learning media. Through this questionnaire, learners also said that they want a similar learning video for other physics materials.

Table 5. Trial results in learners

\begin{tabular}{lcc}
\hline \multicolumn{1}{c}{ Aspects tested } & $\begin{array}{c}\text { Percentage of } \\
\text { Achievements }\end{array}$ & Interpretation \\
\hline Audiovisual display & $90.7 \%$ & Very good \\
Content Quality & $86.1 \%$ & Very good \\
Student worksheet & $86.8 \%$ & Very good \\
integrated video & & \\
Video usability & $94.1 \%$ & Very good \\
\multicolumn{1}{c}{ Average } & $\mathbf{8 9 . 4 \%}$ & Very good \\
\hline
\end{tabular}

\section{Conclusion}

Based on the result of feasibility test by subject expert, media expert, and learning expert, 
and the trials from teachers and high school students, it can be concluded that the instructional video using guided inquiry method in circular motion subject developed is feasible to be used as a physics learning media in senior high school to improved students' learning outcomes in the medium category.

\section{References}

Daryanto, (2013). Media Pembelajaran: peranannya sangat penting dalam mencapai tujuan pembelajaran. Yogyakarta: Gava Media.

Dewi, Ida A.G.B.P. (2014). Perilaku Mencatat dan Kemampuan Memori pada Proses Belajar. Jurnal Psikologi Udayana 1(2), 241-250. Denpasar: Program Studi Psikologi, Fakultas Psikologi, Universitas Udayana.

Hamruni, (2009). Strategi dan model-model pembelajaran aktif menyenangkan. Yogyakarta: Fakultas Tarbiyah UIN Sunan Kalijaga.

Mundilarto. (2002). Kapita Selekta Pendidikan Fisika Yogyakarta: FMIPA UNY.
Prastowo, A. (2014). Panduan kreatif membuat bahan ajar inovatif. Yogyakarta: Diva Press

Putra, N. (2011). Research \& Development penelitian pengembangan. Jakarta: PT Raja Grafindo Persada.

Sani, R. A. (2014). Pembelajaran saintifik untuk implementasi kurikulum 2013. Jakarta: PT Bumi Aksara.

Sanjaya, W. (2013). Strategi pembelajaran: berorientasi standar proses Pendidikan. Jakarta: Kencana Prenadamedia Group.

Sudjana, N. (2004). Penelitian dan penilaian pendidikan. Bandung: PT Sinar Baru Bandung.

Sugiyono. (2011). Metode penelitian kuantitatif kualitatif dan R\&D. Bandung: Penerbit Afabeta.

Sukiman, (2012). Pengembangan Media Pembelajaran Yogyakarta: Pedagogia. 